\title{
IMPLEMENTASI MODEL PENGUATAN KURIKULUM BERBASIS PESANTREN (STUDI KASUS PADA MADRASAH ALIYAH (MA) DI KUDUS)
}

\author{
Ihsan \\ STAIN Kudus \\ Ihsan_dr12@yahoo.co.id
}

\begin{abstract}
Abstrak
Eksistensi Madrasah sebagai lembaga pendidikan semakin kokoh dengan keluarnya Undang-Undang No. 2 Tahun 1989 dan Undang-Undang No. 20 Tahun 2003 beserta berbagai regulasi turunannya. Satu sisi regulasi tersebut telah menghantarkan madrasah pada posisi setara dan sederajat bahkan sama dengan sekolah umum. Namun pada sisi lain kedudukan tersebut menghadapkan madrasah pada tantangan dan dilema yang sulit terutama bila dikaitkan dengan kondisi objektifnya. Dampak secara umum dari status baru tersebut, setidaknya menurut beberapa kalangan tertentu adalah menurunnya kemampuan/penguasaan ilmu agama para lulusan madrasah. Model Penguatan Pendidikan Agama Islam (PAI) dengan mengadopsi sistem pendidikan pesantren ini secara konseptual merupakan manifestasi dari divinity based education. Secara teknis model ini mengadopsi konsep boarding school dan/atau full days school. Dengan konsep ini diharapkan tidak akan ada lagi kendala keterbasan waktu untuk proses pendidikan dan pembelajaran yang berorientasi pada kualitas. Karena dengan konsep ini pendidikan dan pembelajaran di MA tidak hanya dalam formal kurikulum tetapi juga hidden curriculum. Berangkat dari realitas objektif dan tipologi Madrasah Aliyah (MA) di Kudus, Model Penguatan Madrasah Aliyah Berbasis Pesantren sebagai model yang ditawarkan sebagai hasil dari penelitian ini dikelompokkan ke dalam tiga model, yaitu: Madrasah Pesantren, Madrasah Lingkungan Pesantren dan Madrasah Sistem Nilai Pesantren. Implementasi tiga model tersebut bersifat alternatif sesuai dengan konteks dan kapasitas masing-masing MA.
\end{abstract}

Kata kunci: Kurikulum, Pendidikan, Agama Islam, Madrasah

\begin{abstract}
From political and regulatory viewpoints, the existence of Madrasahs as educational institutions get stronger with the issue of Regulation No. 2 Year 1989 and Regulation No. 20 Year 2003 and their derivative regulations. On the one hand, the regulations have helped facilitate the madrasahs get equal footing with public schools - even to some enjoy equal status with public schools - and on the other hand, this new position confronts madrasahs with the challenges due to the fact that many of them have inferior resources. Conceptually, this Islamic boarding-based madrasah model is manifestation of divinity based education concept. Technically, this model adopt concept boarding school and/or full-day school. With this model, it is hoped that there will no more limitation of time to offer quality teaching and education. This model will not only let the madrasahs offer formal curriculum but hidden curriculum as well. Departing from the objective realities and the typology of madrasah aliyah in Kudus, the Islamic boarding-based madrasah as a model offered in this study is classified into three different models, i.e. Pesantren (Islamic boarding) madrasah, Pesantren Environment Madrasah, and
\end{abstract}


Pesantren Values System Pesantren. As to implement these models, it is suggested that the madrasah will choose either one of the three which suits best to their contexts and capacities.

Keywords: Curriculum, Education, Islamic religion, madrasah

\section{A. Pendahuluan}

Madrasah sebagai lembaga pendidikan merupakan modernisasi transformasi lembaga pendidikan Islam tradisional, pesantren (Madjid, 1997:110-135).Secara kultural, pesantren adalah bentuk adaptasi dan islamisasi sistem pendidikan pra Islam, masa Hindu-Budha(Moestopo, 2001:150). Sebagai lembaga pendidikan dan sekaligus lembaga keagamaan dengan tradisi besarnya (great tradition), pesantren telah membuktikan kiprahnya dalam mencerdaskan kehidupan umat. Kendatipun seiring berjalannya waktu, pesantren sebagai lembaga pendidikan dipandang kurang atau belum mampu membekali para santrinya dengan kompetensi praktis untuk berkarya, terutama untuk sektor formal. Fakta tersebut mendorong para tokoh muslim lulusan Timur Tengah tergerak untuk membuat format pendidikan baru dengan mengadopsi sistem persekolahan Barat dengan nama madrasah.

Perjuangan untuk mendapatkan pengakuan kesetaraan dan kesederajatan, mulai mendapatkan hasil, terutama pada era Orde Baru, atau lebih tepatnya setelah eksistensi madrasah mulai mendapatkan perhatian dari pemerintah di bawah naungan, pengelolaan serta pengawasan Kementerian Agama. Secara politis dan yuridis eksistensi tersebut menjadi semakin kuat dengan lahirnya Undang-Undang Nomor 2 Tahun 1989 tentang Sistem Pendidikan Nasional, dan Peraturan Pemerintah Nomor 28 dan 29 Tahun 1990 dimana madrasah mendapat predikat atau nama baru sebagai "sekolah umum yang berciri khas Islam".Eksistensi madrasah secara yuridis semakin kokoh dengan keluarnya Undang-Undang Nomor 20 Tahun 2003, dimana antara madrasah dan sekolah memiliki kedudukan yang sama. Pembedaan, pada madrasah, mata pelajaran pendidikan agama lebih banyak dibandingkan dengan sekolah umum.

Secara Nasional, sebagai sekolah umum dengan ciri khas Islam, madrasah diharapkan menjadi lembaga pendidikan plus dengan keunggulan komparatifnya, 
yaitu penekanan yang signifikan pada pendidikan agama dan akhlak (moralitas), tentu disamping itu juga pada penguasaan mata pelajaran umum. Dengan ciri khas tersebut diharapkan madrasah mampu menjadi "pendidikan alternatif" di tengah kegelisahan masyarakat akan kurangnya pemahaman nilai agama dalam kehidupan sehari-hari. Hal positif lain yang mendukung keunggulam madrasah adalah kenyataan kecenderungan new attachment kepada Islam dan lahirnya muslim rising middle class pada masyarakat yang semakin berusaha mendapatkan pendidikan Islam yang berkualitas bagi anak-naknya (Azra, 2003: 54). Fakta ini sekaligus menjadi peluang dan tantangan bagi madrasah untuk mampu memenuhi harapan para stakeholder, khususnya orang tua murid yang menghendaki anakanaknya memperoleh pengetahuan agama dan umum secara memadai khususnya untuk tingkat Madrasah Aliyah (MA).

Problem dan sekaligus menjadi kegelisahan terkait dengan output MA yang masih dan terus dirasakan oleh MA adalah rendahnya kemampuan atau kompetensi keagamaan (penguasaan pengetahuan agama Islam), sehingga ciri khas Islam sebagai identitas dan jati diri madrasah menjadi tidak atau kurang kelihatan secara maksimal. Oleh karena itu, tidak mengherankan jika masyarakat menilai sebagian besar lulusan MA saat ini kehilangan jati diri ke-madrasahannya sesuai konteks historis kelahirannya sebagai lembaga pendidikan kader calon ulama. Sementara penguasaan atau capaian hasil belajar bidang sains atau pengetahuan umum jauh ketinggalan bila dibandingkan SMA.

Upaya mempertahankan, mengejar ketertinggalan dan melengkapi kekurangan tersebut muncul fenomena di beberapa MA di Kudus yang menyelenggarakan sistem pendidikannya dengan mengadopsi sistem pendidikan pesantren. Langkah ini ditempuh antara lain untuk menambah jam pembelajaran sehingga memungkinkan proses penguatan dan pengayaaan materi kurikuler sesuai standar isi. Khusus terkait materi Pendidikan Agama Islam, sistem ini dijadikan sebagai media untuk implementasi pengembangan kurikulum, baik dalam arti subject matter maupun sistem dan model pembelajarannya.

Berdasar pada pemaparan tersebut di atas, adapun rumusan masalah dalam artikel ini adalah bagaimana desain dan implementasi kurkulum berbasis 
pesantren mampu menguatkan program pendidikan agama Islam secara maksimal? Atas dasar pertimbangan dan realitas tersebut, sebagai praktisi dan akademisi penulis terdorong untuk menjawab fenomena tersebut sekaligus menawarkan solusi atas berbagai problem dan kendala yang dihadapi oleh lembaga pendidikan Islam.

\section{B. Metode Penelitian}

Sesuai dengan tujuan penelitian ini, maka secara metodologis penelitian ini dibagi kedalam dua tahap. Pertama, mendeskripsikan realitas MA di Kudus secara menyeluruh sebagai lembaga pendidikan. Dari temuan deskriptif tahap pertama itulah selanjutnya dijadikan dasar untuk memasuki tahap kedua, yaituperumusan model. Untuk mendapatkan gambaran yang utuh dan menyeluruh (holistik) tentang apa dan bagimana realitas MA di Kudus maka pilihan metodologis yang tepat untuk penelitian ini adalah kualitatif paradigma naturalistik. Secara filosofis, sesuai dengan karakter data, teknik pengumpulan dan analisis penelitian ini mengacu pada Post-positivisme-Phenomenologi (Muhadjir,2002:17) Tahap selanjutnya setelah diperoleh deskripsi tentang realitas dan ragam pengelolaan kelembagaan dan pembelajaran MA adalah merumuskanmodel sebagai bentuk inovatif dalam rangka meningkatkan kualitas pembelajaran, khususnya untuk meningkatkan penguasaan pengetahuan agama Islam. Secara metodologis pendekatan yang dipilih untuk tujuan tersebut adalah dengan model social action, dimana peneliti melibat langsung dan menyatu dengan subyek penelitian dalam berbagai aktivitas madrasah dan berpartisipasi aktif.

\section{Hasil Penelitian dan Pembahasan}

\section{Kategorisasi Madrasah Aliyah di Kudus}

Atas dasar identifikasi problem dan latar yang berbeda, MA di Kudus dapat dikelompokkan menjadi dua kategori, yaitu MA yang lahir sebelum dan sesudah keluarnya Undang-Undang Nomor 2 Tahun 1989. Pembedaan ini menjadi penting tidak hanya sekedar untuk mengetahui usia suatu MA, tetapi yang lebih penting adalah karena keluarnya undang-undang tersebut merupakan momentum besar 
bagi pengakuan madrasah dalam sistem pendidikan nasional. Problem utama yang dihadapi oleh madrasah sebelum lahirnya undang-undang tersebut adalah legitimasi, maka tema perjuangan umat Islam pada saat itu (sebelum keluar undang-undang) adalah pengakuan akan kesetaraan dan kesederajatan. Penyebab utama tidak diakuinya madrasah (lulusan madrasah) pada saat itu karena muatan isi kurikulum madrasah berbeda dengan sekolah umum, sehingga kompetensi lulusannya dianggap berbeda. Pada dataran praktis, terutama untuk sektor formal, lulusan madrasah tidak memperoleh hak-hak yang semestinya seperti yang diperoleh lulusan sekolah umum. Keadaan ini kemudian menjadi berubah dengan keluarnya undang-undang tersebut, dengan konsekuensi muatan isi kurikulum madrasah harus sama dengan kurikulum sekolah umum. Perubahan tersebut, seperti digariskan dalam Peraturan Pemerintah Nomor 29 Tahun 1990 dan Surat Keputusan Menteri Pendidikan dan Kebudayaan Nomor 0489/U/1992, kurikulum madrasah harus $100 \%$ sama dengan sekolah umum.

Madrasah dalam statusnya sebagai lembaga pendidikan Islam, maka muatan isi kurikulum madrasah pada awal kelahirannya, sesuai visi dan tujuannya adalah ilmu-ilmu agama ('ulu>m $a l-d i>n)$, ilmu pengetahuan umum hanya sebagai pelengkap atau tambahan. Keadaan inilah yang menjadikan MA di Kudus yang lahir sebelum dan sesudah tahun 1989 memiliki karakter yang berbeda. MA yang lahir (setidaknya embrio kelahirannya) sebelum tahun 1989 karakter dan orientasi keagamaanya sangat kuat, sehingga secara kelembagaan memiliki kesamaan substansial dengan sistem pendidikan pesantren. Sedangkan MA yang lahir sesudah tahun 1989, kurikulum dan sistem pembelajarannya sepenuhnya mengadopsi sistem persekolahan dengan pengayaan bidang Pendidikan Agama Islam (PAI). Dilihat dari kompetensi dan penguasaan ilmu agama Islam MA kategori ini tidak jauh berbeda dengan lulusan SMA. Hal ini dapat dilihat dalam struktur kurikulum, jenis mata pelajaran, sistem pembelajaran, dan orientasi kelembagaan.

Hanya ada 2 dari 36 MA di Kudus yang berstatus negeri, selebihnya adalah MA yang lahir dan berkembang atas prakarsa dan inisiatif masyarakat. Dari 2 MA berstatus negeri itupun salah satunya (MAN 1 Kudus) melalui proses penegerian, 
artinya awal kelahirannya adalah atas prakarsa masyarakat. Sementara yang lainnya adalah (MAN 2 Kudus) hasil konversi dari PGAN Kudus. Sebagai lembaga pendidikan yang didirikan oleh masyarakat, maka visi dan cita-cita para tokoh pendiri MA swasta tersebut sangat mempengaruhi arah dan perkembangan MA tersebut. Hal penting terkait dengan para tokoh tersebut adalah latar belakang para tokoh pendiri suatu MA. Latar belakang yang dimaksud di sini adalah latar belakang pendidikan dan profesi/kedudukan sosial para tokoh tersebut di masyarakat. Hampir semua MA swasta di Kudus didirikan atas prakarsa tokoh agama (ulama') dan tokoh masyarakat pada tingkatan masing-masing. Semakin tinggi tingkat ketokohan (popularitas) para pendiri, akan menjadi daya tarik bagi masyarakat untuk menyekolahkan anaknya ke suatu MA. Aspek ketokohan yang sangat diperhatikan oleh masyarakat adalah tingkat ke-ulama'-an tokoh pendiri.

Hampir semua MA swasta di Kudus yang didirikan sebelum tahun 1989, tokoh pendirinya adalah para kyai (ulama') besar di Kudus, dengan latar belakang pendidikan pesantren, rata-rata memiliki pondok pesantren atau setidaknya memiliki forum pengajian tetap (majlis ta'lim) di masjid atau musholla. Latar belakang pendidikan pesantren inilah yang mewarnai visi akademik/keilmuan yang dikembangkan dalam kurikulum MA. Karena terlalu banyaknya ilmu agama yang diberikan, MA jenis ini lebih mirip dengan pesantren dibanding madrasah. Sedangkan MA yang berdiri setelah tahun 1989 sebagian besar didirikan oleh tokoh masyarakat (bukan kategori kyai/ulama') yang peduli terhadap pendidikan (Islam), bahkan beberapa di antara para tokoh pendiri MA ini adalah para pamong/perangkat desa. Meskipun demikian proses pendiriannya tetap melibatkan peran para ulama'/kyai lokal.

Ditinjau dari kemampuan manajemen, kekuatan MA di Kudus dapat dikelompokkan menjadi maju, sedang, dan kurang. Indikatornya: 1) ketersediaan dan kecukupan infrastruktur kependidikan, 2) ketersediaan dan kecukupan tenaga pendidik sesuai kualifikasi dan kompetensi, dan 3) jumlah peserta didik. Ketiga faktor tersebut, faktor jumlah peserta didik menjadi dominan dan determinan dalam menentukan faktor pertama dan kedua. Semakin banyak jumlah siswa maka 
akan semakin tercukupi infrastruktur kependidikan dan terpenuhi jumlah guru yang dibutuhkan.

Sedangkan dari sisi status kelembagaannya, dikelompokkan menjadi MAN dan MAS. Pengelompokan MA menjadi negeri dan swasta ini tidak hanya dimaksudkan untuk melihat status kelembagaan yang berimplikasi pada aspek administratif (kapasitas manajemen) semata, tetapi yang lebih penting adalah terkait dengan aspek yang lebih mendasar yaitu visi akademik dan orientasi pembelajarannya, yang berujung kepada perbedaan substantif MAN dan MAS. Berbeda dengan MA negeri yang keberadaannya dalam banyak hal diatur, ditentukan dan difasilitasi oleh pemerintah, kehadiran dan keberadaan madrasah swasta di tengah-tengah masyarakat benar-benar atas ide, prakarsa/upaya dari masyarakat, termasuk dalam hal pembiayaan. Pada satu sisi kemandirian madrasah swasta tersebut sangat positif dalam konteks kreasi dan inovasi, namun pada sisi lain kemandirian terutama dalam bidang pembiayaan justru menjadi kendala berat bagi madrasah swasta untuk melaksanakan kreasi dan inovasi sesuai tuntutan zaman.

Berdasarkan data yang penulis kumpulkan, ada perbedaan signifikan antara MA negeri dan MA swasta dalam memahami dan memaknai ciri khas Islam. Untuk MA negeri implementasi ciri khas Islam diwujudkan dalam bentuk penjabaran rumpun PAI menjadi lima mata pelajaran, sedangkan untuk MA swasta penjabaran PAI menjadi lima mata pelajaran tersebut dianggap belum mampu mewujudkan jati diri dan roh MA sebagai lembaga pendidikan Islam. Oleh karenanya, perlu penambahan atau bahkan perombakan komposisi PAI tersebut dan melengkapinya dengan beberapa ilmu pendukung yang relevan (ilmu alat) yang dibutuhkan untuk kepentingan memahami teks sumber ajaran (alQur'an dan al-Hadith) dan berbagai kitab klasik yang relevan. Atas dasar pertimbangan inilah, maka di beberapa MA yang berorientasi kuat ilmu-ilmu agama Islamnya, materi dan sistem pembelajarannya hampir sama dengan pesantren. Hal ini berbeda dengan MA negeri yang sama dengan SMA, bila ada perbedaan hanyalah sedikit yaitu pada penjabaran PAI. 
Berangkat dari realitas implementasi ciri khas Islam sebagaimana tercermin kegiatan inti kependidikannya (kurikulum/standar isi dan kompetensi lulusan/standar kompetensi lulusan), MA di Kudus penulis kelompokkan kedalam empat tipologi. Empat tipologi MA tersebut meliputi: (1) MA sebagai SMU berkarakter agama, (2) MA berkarakter pesantren, (3) MA berkarakter Pengayaan Agama, dan (4) Pesantren dengan madrasah formal.

\section{Paradigma Baru Kurikulum Berbasis Pesantren}

Pesantren sebagai lembaga pendidikan "tradisional", memiliki kelebihan dalam hal kemengakaran pada tradisi Islam. Kemengakaran ini terdapat pada pendasaran pendidikan Islam kepada keilmuan Islam klasik, yang merujuk pada pembelajaran mendalam atas sumber utama teks Islam (al-Qur'an dan al-hadist). (Mastuhu,1994:55-70.) Pembelajaran mendalam atas dua sumber utama ini dipraksiskan dalam operasionalisasi nilai-nilai Islam melalui pembelajaran atas bidang-bidang keilmuan yang menjadi dasar-dasar keagamaan $(u s\} u>l$ al-di $>n)$. Dasar-dasar ini merujuk pada pembelajaran atas fiqh beserta $u s\} u l$ dan qawa' $i>d$ al-fiqh, tafsir dan $u l u>m$ al-h;adi $>s \mid$, ilm kala $>m$, dan tasawwuf. Guna mencapai pembelajaran maksimal atas $u s, u>l$ al-di $>n$ ini, pesantren kemudian memperkuat santri dengan penguasaan atas ilmu-ilmu 'alat, yang mencakup ilmu bahasa Arab (nahwu, sharaf, balghah), mantiq, serta kebiasaan pemaknaan kitab kuning baik melalui metode sorogan maupun bandongan (Mastuhu, 1994: 61). Oleh karena itu, pendidikan pesantren mencukupi dalam melakukan pendidikan tradisional Islam, sehingga santri bisa mendalami keilmuan Islam, tepat dari sumber utama peradaban Islam. Simbolisasi atas kemampuan pesantren dalam mengakarkan pendidikannya kepada tradisi keilmuan Islam, merupakan corak ideal suatu proses pendidikan, karena mampu menciptakan kesinambungan historis, epistemologis, normatif, kultural dan didaktis dalam kerangka besar peradaban Islam (Azra, 2003: 102).

Kesinambungan historis artinya, pesantren mampumempertemukan santri dengan kesejarahan Islam (Muhaimin, et al.,2002: 118). Kesadaran dan penguasaan atas kesejarahan Islam ini akan membuahkan muslim yang mampu 
memaknai keberislaman berdasarkan pembentukan historis keislaman tersebut. Kesadaran dan penguasaan historisitas Islam ini penting, karena di madrasah, hal ini tidak begitu maksimal diupayakan. Ketidakmaksimalan proses historisasi pendidikan Islam telah membuahkan siswa muslim yang tidak bisa menumbuhkan pemahaman keislaman dalam pemahaman eksistensial. Akhirnya pendidikan Islam minus pemahaman kesejarahan, telah membuahkan pendidikan partikularis yang fungsional dan pragmatis (Madjid, 1977: 21). Artinya siswa hanya diberikan pengetahuan Islam secara terpisah-pisah, tanpa keutuhan pemahaman. Historisasi pendidikan Islam tidak bisa dilakukan hanya melalui pembelajaran atas sejarah Islam. Melainkan melalui penghadiran segenap suasana, prestasi kultural, dan nilai-nilai keislaman dalam pembentukan historisnya. Dengan menghadirkan pendidikan Islam yang tradisional di atas, pesantren telah menghadirkan kesejarahan Islam dalam sistem pendidikannya, sehingga siswa bisa hidup dalam kerangka kesejarahan dan peradaban Islam tersebut.

Sementara itu kesinambungan epistemologis adalah kesinambungan cara berpikir dalam kerangka keislaman, yang membuat pesantren tidak hanya merupakan pendidikan agama Islam, melainkan pendidikan menurut Islam. Hal ini yang melahirkan kesinambungan normatif, yang membuahkan pemahaman dan pengamalan atas apa yang baik dan apa yang buruk menurut Islam di dalam pesantren. Normativisme Islam ini tidak akan dimiliki madrasah yang tidak benarbenar mengakarkan pendidikannya pada historisitas dan epistemologi keislaman itu sendiri. Dari normativitas inilah pesantren merupakan kesinambungan kultural dari peradaban Islam, karena ia terbangun di atas prestasi kultural sejarah Islam. Kesinambungan kultural ini yang dikemudian dipraksiskan melalui sistem didaktis, yang membuat sistem pendidikan pesantren bisa menjadi cerminan bagi originalitas peradaban Islam itu sendiri (Azra, 2002: 109-110).

Pada kenyataannya segenap kelebihan ini masih terbayangi oleh kelemahan sistem pendidikan pesantren, yang membuat pemerintah Indonesia mendaulat madrasah sebagai sistem pendidikan Islam yang resmi. Kelemahan ini terletak pada kurangnya manajemen modern di dalam tata pendidikan, yang mengacu pada sistem administrasi kurikulum dan penataan institusional berbasis birokrasi (Azra, 
2002: 109-110). Dengan kurangnya sistem administrasi ini, maka pendidikan pesantren (klasik) cenderung bersifat kultural: santri belajar karena ingin menjadi muslim yang baik, dan bisa mengajar menjadi ustadz di kampungnya, ketika ia lulus mesantren. Materi pelajaran yang hanya mengacu pada pelajaran Islam klasikpun dianggap terbelakang, karena meminggirkan ilmu-ilmu umum yang dibutuhkan santri untuk menghadapi situasi modern yang menuntut penguasaan sains dan teknologi. Maka, karakter santri sebagai pelajar Islam yang kikuk dengan perkembangan zamanpun terjadi, yang semakin menyudutkan pesantren sebagai lembaga pendidikan yang ketinggalan zaman.

Berangkat dari kelemahan inilah pemerintah dan praktisi pendidikan kemudian menggagas sistem madrasah, yang merupakan internalisasi sistem pendidikan sekolah ke dalam pendidikan Islam. Artinya, madrasah adalah tipe keislaman dari pendidikan sekolah. Oleh karena itu, paradigma awal madrasah adalahparadigma sekolah. Dengan paradigma ini, sistem pendidikan madrasah secara institusional dan administratif, mengacu pada sistem sekolah. Dengan demikian maka sahlah jika madrasah disebut sebagai pendidikan agama Islam. Yakni sistem pendidikan yang mengajarkan agama Islam. Bukan sistem pendidikan menurut Islam. Mengapa? Karena paradigma dan sistem pendidikan madrasah adalah sekolah. Di titik inilah kita menjadi mafhum kenapa definisi madrasah adalah sekolah umum berciri khas Islam. Jawabnya jelas: madrasah adalah salah satu bidang pendidikan sekolah yang konsen dengan pengajaran ilmu-ilmu keislaman.

Tentu hal ini memiliki kelebihan, karena sistem sekolah dengan manajemen institusional dan administrasi kurikulum, telah membuahkan sistem pendidikan modern yang tertata rapi dan bisa beradaptasi dengan perkembangan zaman. Keberadaan ilmu-ilmu umum yang mendampingi ilmu-ilmu keislaman, membuat pelajar madrasah bisa mempelajari dua corak keilmuan sekaligus, sehingga mereka tidak kikuk dengan kondisi masyarakat yang serba saintifik dan teknologis.

Hanya saja corak dominan dari sistem sekolah di dalam madrasah inilah, yang membuat pendidikan Islam kehilangan otentisitasnya. Hal ini terjadi karena 
dasar bangunan institusionalnya bukan dari dasar bangunan peradaban Islam, melainkan dari sistem sekolah yang cenderung sekular (Fealy(ed),1997:171). Dominasi sistemik ini kemudian diperkuat oleh dominasi jumlah mata pelajaran umum yang hampir 70\%, membuat pelajaran keislaman menjadi sangat minim. Oleh karena itulah pelajaran Islam di madrasah bisa disebut sebagai pelajaran Islam minimalis, karena jumlah dan ukurannya yang minimalis sehingga tidak mencukupi bagi maksimalisasi pendidikan Islam.

Berangkat dari kelemahan dan kelebihan tersebut, perlu dilakukan sintesis yang mengarah pada pembentukan suatu sistem pendidikan kurikulum berbasis pesantren. Hal ini dilatari oleh beberapa hal. Pertama, sistem pendidikan yang resmi adalah madrasah. Oleh karena itu, pengembangan dan perbaikan sistem pendidikan Islam haruslah beranjak dari sistem madrasah. Kedua, secara institusional, madrasah memang memiliki kelebihan dibanding pesantren, yakni dalam tata administrasi dan birokrasi pendidikan. Hal ini merupakan pengelolaan modern atas sistem pendidikan, yang membuat sistem madrasah terukur, jika dibanding dengan pola pesantren yang lebih bersifat kultural. Ketiga, pesantren di sisi lain memiliki kelebihan yang bisa menyempurkan sistem pendidikan Islam di madrasah. Kelebihan ini terletak pada sistem pendidikannya yang mengakar pada tradisi keilmuan Islam dan tradisi dari peradaban Islam itu sendiri. Keempat, dengan demikian, upaya penyempurnaan pendidikan Islam kita haruslah mengarah pada pendasaran kembali sistem pendidikan Islam kepada tradisi Islam, meskipun tetap dengan tata kelola institusional ala madrasah. Di dalam proses penyempurnaan ini, tentu ada hal-hal dari madrasah yang dikurangi. Upaya ini merupakan usaha untuk mendedominasikan sistem sekolah atas pendidikan Islam. Salah satunya melalui penambahan mata pelajaran keilmuan Islam, sehingga pelajaran Islam tidak lagi minimalis, melainkan maksimalis.

Memang di satu titik telah terjadi persilangan antara madrasah dan pesantren: pesantren mendirikan madrasah di dalamnya dan madrasah memiliki sistem nilai dan kurikulum pesantren. Pada yang pertama, pesantren telah menyempurnakan diri sehingga mau memasukkan pola sistem sekolah ke dalam sistem pendidikan tradisionalnya. Hal ini tentu menggugurkan tesis 
keterbelakangan pesantren. Hal sama terjadi pada madrasah yang telah mengadopsi sistem nilai dan kurikulum pesantren. Dalam kaitan ini, madrasah telah menyempurnakan diri melalui pesantrenisasi sistem pendidikannya.

\section{Model Penguatan Kurikulum berbasis pesantren}

Gagasankurikulum berbasis pesantren berangkat dari kebutuhan untuk merumuskan suatu sistem pendidikan Islam yang baru. Kebaruan dari sistem ini terletakpada basis filosofisnya, yang hendak menjadikan kepesantrenan sebagai basis pendidikan dari madrasah (Fadjar, 1995:513-514). Disebut basis filosofis, karena kurikulum berbasis pesantren berangkat dari kehendak untuk mengembalikan sistem pendidikan madrasah kepada dasar filosofis dari pendidikan Islam yang menurut penulis terdapat di pesantren. Secara jujur harus diakui bahwa saat ini telah terjadi defilosofisasi pendidikan Islam di madrasah, yang berujung pada tercerabutnya dari landasan filosofis pendidikan Islam itu sendiri. Proses defilosofi ini terjadi, akibat proses instrumentalisasi, pragmatisasi, fungsionalisasi, dan mekanisasi pendidikan Islam madrasah, yang membuatnya tercerabut dari nilai-nilai dasar pendidikan Islam.

Hal tersebut tentu bertentangan dengan filsafat pendidikan Islam yang berangkat dari rasionalitas nilai, (Zuhairi, dkk., 1995:107-120) bukan rasionalitas instrumental. Rasionalitas nilai dalam pendidikan Islam menyatakan bahwa hakikat pendidikan dalam Islam adalah pembentukan karakter manusia berdasarkan ontologi keislaman. Ontologi manusia ini berisi tentang konsep "manusia ideal" menurut Islam, yaitu sebagai hamba ('abdullah) dan wakil Tuhan (khalifatullah). Sebagai hamba, manusia harus mengarahkan hidupnya untuk beribadah. Menjadi hamba Tuhan. Sementara sebagai khalifatullah, manusia adalah pengejawantahan nilai-nilai ketuhanan sehingga dunia bisa ditata dengan nilai-nilai tersebut.

Dari ontologi keislaman manusia inilah, pendidikan Islam dibangun. Jadi pendidikan Islam adalah pendidikan yang dibangun berdasarkan rasionalitas nilainilai ontologi Islam atas hakikat manusia. Oleh karena itu, elemen keilmuan dalam pendidikan Islam, haruslah mampu memenuhi kebutuhan bagi 
pembentukan manusia Islami. Dalam kaitan ini, pemenuhan tersebut akhirnya memuara pada dua tugas manusia sebagai 'abdullah dan khalifatullah (Syed Muhammad, 1978:18). Dari dua tugas kehambaan dan kekhalifahan ini, maka tidak ada lagi dikotomi pendidikan agama dan pendidikan umum. Sebab demi pemenuhan tugas kekhalifahan, muslim haruslah mengetahui seluk-beluk dunia, agar ia bisa menata dunia dengan baik. Muslim haruslah menguasai ilmu politik, antropologi, ilmu budaya, ilmu bahasa, ilmu sosial, filsafat, ilmu teknik, dan segenap tradisi pengetahuan tentang manusia dan masyarakat yang tidak berasal dari khasanah keislaman. Standar keislaman dalam tugas penataan dunia kemudian bisa berarti dua macam. Bisa bersifat formalis, dalam artian, pelajar Islam menggunakan konsep Islam (misalnya politik Islam) sebagai rumusan penataan dunia. Atau bersifat substantif. Yakni memasukkan nilai-nilai dasar keislaman dalam ruang lingkup yang tidak Islami.

Pada titik inilah, praktek filsafat pendidikan Islam hanya bisa diterapkan dalam bentuk Kurikulum berbasis pesantren. Tentu, pola idealnya sudah diterapkan secara nyata di pesantren. Dalam hal ini, pesantren sebagai sub-kultur yang secara ideal telah memuat tiga sistem nilai pesantren seperti termaktub di atas. Hanya saja karena secara legal, lembaga pendidikan Islam formal di Indonesia adalah madrasah, maka pembentukan sistem pendidikan Islam yang ideal, berarti pertemuan antara konsep madrasah dan konsep pesantren. Dalam kaitan ini, pesantren sebagai nilai dan sistem pedagogis penulis jadikan basis pedagogis dari sistem pendidikan madrasah. Oleh karenanya, perumusan sistem baru pendidikan ini tidak harus membuahkan lembaga pendidikan yang benarbenar baru, yang belum ada selama ini. Perumusannya terdapat pada penempatakn kepesantrenan sebagai basis pedagogis dari madrasah. Dari sini basis pedagogis itu meliputi beberapa hal. (1) basis nilai, (2) basis pengajaran, (3) basis kultural.

Dengan ketiga basis tersebut madrasah sebagai sistem teknis dari pendidikan Islam, akan memiliki basis yang mendasar, yakni pesantren. Artinya, madrasah yang memiliki kekuatan pada sisi manajemen rasional dan birokrasi pendidikan, disempurnakan oleh basis dari pendidikan itu sendiri, yakni pesantren. Dengan demikian, madrasah yang saat ini disebut sebagai sekolah 
berciri khas Islam, tidak akan menjadi sekolah murni yang kehilangan ciri khas Islamnya. Ia tidak akan terjebak ke dalam jeruji sistem birokratis yang tercerabut dari akar filosofis pendidikan Islam. Madrasah sebagai sistem teknis, akhirnya bisa bermanfaat sebagai pengaturan rasional bagi nilai-nilai filosofis pendidikan Islam.

Dengan cara ini, paradigma instrumental (Lukens-Bull, 2004:149)yang menjadi landasan pembentukan madrasah, akhirnya berganti dengan rasionalitas nilai. Madrasah dijalankan untuk mengabdi kepada nilai-nilai mendasar Islam. Dengan cara ini pula, siswa tidak akan terjebak dalam sistem tertutup madrasah. Mereka mampu kembali kepada naturalitas dan kulturnya. Artinya, madrasah akan mengembalikan siswa kepada kewajaran natural sebagai manusia yang berhak berkembang, berinovasi dan merubah diri. Sifat natural dari manusia ini yang meniscayakan sistem pendidikan terbuka. Sebab naturalitas manusia selalu berkembang dan berubah, dan ia tentu membutuhkan sistem dinamis yang memenuhi kebutuhan bagi pengembangan diri tersebut. Dengan gagasan kurikulum berbasis pesantren, siswa tidak akan terjebak menjadi objek pedagogis dari sistem birokratis, tetapi berkultural pesantren.

Konsep kurikulum berbasis pesantren ini adalah adopsi nilai dan sistem pesantren dalam pengelolaan MA sebagai "sekolah umum" dengan Islam sebagai "ciri khasnya". Tujuan dari konsep ini adalah dalam rangka penguatan atas berbagai kekuarangan yang terjadi pada MA, terurtama bidang PAI. Merujuk pada SI dan SKL, perbedaan antara MA dan SMA adalah terletak pada tujuan dan cakupan materi PAI. Tujuan mata pelajaran PAI di SMA adalah: (1) memberikan wawasan terhadap keberagaman agama di Indonesia, (2) meningkatkan keimanan dan ketaqwaan siswa. Karena rumusan tujuannya yang lebih simpel (global), maka PAI untuk SMA diberikan secara global dalam satu mata pelajaran. Berbeda dengan SMA, karena Islam menjadi ciri khasnya maka komposisi PAI untuk MA menjadi lebih banyak (mata pelajaran dan alokasi waktu) dan pembahasannya lebih mendalam dalam rangka mencapai tujuan spesifiknya. Sebagai sub-sistem pendidikan nasional, ada tiga tujuan yang harus di capai oleh MA, yaitu: (a) tujuan pendidikan nasional, (b) tujuan pendidikan menengah, dan (c) tujuan 
spesifik pendidikan MA.

Karena mengadopsi nilai dan sistem pesantren maka operasional kegiatan madrasah menerapkan model boardingschool (asrama) dengan mengadopsi konsep sistem "pondok" atau pemondokan bagi para santri sebagaimana telah lama diterapkan dalam sistem pendidikan pesantren. Unsur esensial yang diadopsi dari sistem ini adalah pada aspek sistem full days school, dimana proses belajar mengajar bisa dilaksanakan tidak hanya pada aspek kurikulum formal saja tetapi juga pada aspek hidden curriculum.

Dengan mengadopsi sistem pesantren ini, secara umum ada empat hal penting yang dapat dicapai atau diperoleh secara simultan oleh MA dalam kapasitas dan statusnya sebagai sekolah menengah umum berciri khas Islam. Capaian ini sekaligus merupakan keunggulan dan kelebihan MA bila dibandingkan dengan SMA atau pendidikan Islam tradisional lainnya. Bila hal ini dapat diwujudkan, maka akan tercipta produk (output-outcome) dari proses pendidikan di MA yang sesuai dengan ekspektasi para penggunanya. Empat hal tersebut meliputi: (1) penguatan atau pendalaman 'ulu>m al-dīn sebagai upaya untuk meningkatkan kualitas pengetahuan dan keberagamaan peserta didik. (2) Pendalaman materi science (mata pelajaran umum) sebagai upaya untuk mencapai keunggulan komparatif sejalan dengan arus besar kebijakan pendidikan nasional. (3) Pemberian latihan ketrampilan untuk memberi bekal life skill sebagai bekal bagi lulusan untuk terjun dalam kehidupan bermasyarakat dengan keunggulan kompetitif. (4) Optimalisasi kegiatan ekstra dalam rangka mewujudkan "pendidikan yang dijiwai dengan suasana keagamaan". Adapun model yang dilahirkan dari paradigma kurikulum berbasis pesantren adalah:

Pertama, Madrasah Pesantren (MP) adalah model pengelolaan MA, dimana secara operasional pengelolaan antara madrasah dan pesantren berada dalam satu sistem manajemen. Artinya, suatu MA tidak hanya secara fisik berada dalam lingkungan pesantren tetapi antara MA dan pesantren berada dalam satu struktur organisasi dan manajemen yang menyatu (integreted). Tujuan dari penyatuan sistem pengelolaan ini adalah agar semua proses pendidikan berada dalam suatu sistem yang memungkinkan semua kegiatan guru dan murid berada dalam satu 
alur dan paket program yang sama.

Kedua, Madrasah Lingkungan Pesantren (MLP), madrasah yang berada di lingkungan Pesantren yang disingkat MLP ini secara substantif memiliki kesamaan dengan model yang pertama, perbedaannya hanyalah terletak pada keberadaan pesantren secara pisik. Bila pada model pertama MA dan pesantren berada dalam satu sistem pengelolaan dan dalam satu kompleks pendidikan, untuk model yang kedua antara MA dan pesantren tidak berada dalam satu sistem manajerial. Pesantren yang di maksud disini adalah pesantren yang secara pisik berada dalam satu kawasan atau lingkunguan di sekitar lokasi MA. Model ini sekaligus menjadi alternatif bagi MA yang memiliki keterbatasan dalam penyiapan infrastruktur. Karena berada di luar manajemen dan tidak berada dalam satu komplek pendidikan, langkah yang bisa ditempuh oleh para pengelola MA adalah dengan mengadakan kerja sama dengan pihak pengelola/pengasuh pesantren dalam hal materi (ilmu agama) yang diajarkan di pesantren. Oleh karena itu, dari sudut pengelolaan kelembagaan model MLP ditempuh melalui kerjasama antara manajemen madrasah pada satu pihak dan manajemen pesantren pada pihak lain. Dengan kerja sama ini diharapkan sistem dan materi pendidikan yang dijarkan di pesantren bisa sejalan dan mendukung tema-tema yang diajarkan di MA.

Dari sudut materi atau bahan yang diajarkan, rumusan verbalnya bisa jadi antara apa yang diajarkan di madrasah dan di pesantren berbeda. Namun substansi isi bahan yang diajarkan ada titik temu. Meskipun dari sudut kelembagaan antara madrasah dan pesantren merupakan unit organisasi atau lembaga yang berbeda, namun pembelajaran di pesantren didesin dalam rangka penguatan (empowering) terhadap materi yang diajarkan di madrasah. Karena berbeda lembaga maka antara keduanya hubungannya bersifat koordinatif dalam rangka menjalin sinergi demi menghindarkan terjadinya ketidaksesuaian isi dari materi pembelajaran. Karena merupakan unit organisasi yang berbeda, maka model pmanajemen/kepemimpinan antara madrasah dan pesantren tidak harus menyatu, karena untuk menyatu membutuhkan beaya infrastruktur yang mahal. Akan tetapi antara madrasah dan beberapa pesantren yang berada di 
lingkungannya ada kerjasama dan koordiniasi.

Kerjasama dimaksud terkait dengan materi kurikulum, tata tertib, jadwal kegiatan, dan hal-hal teknis lainnya. Dalam sistem pendidikan dan pembelajaran, secara operasional pembelajaran di pesantren berjalan sesuai dengan karakter dan materi masing-masing pesantren. Dengan asumsi bahwa pembelajaran di pesantren berorientasi pada $u l u>m$ al-di>n, maka hasil pembelajaran tersebut otomatis akan memperkaya dan melengkapi materi agama Islam di kurikulum madrasah. Dalam rangka penciptaan lingkungan yang kondusif untuk belajar dan Islami, pesantren yang berada di lingkungan madrasah tersebut berjalan sesuai dengan kultur dan nilai yang ada dan berjalan selama ini. Dengan kata lain pengelola pesantren memiliki otonomi dan deskresi untuk melaksanakan kegiatan pendidikan dan pengajaranannya, khususnya untuk materiulu>m al-di>n. Output yang diharapkan dari sistem ini adalah penciptakan pribadi siswa/santri yang berakhlaqul karimah. Terkait dengan pembelajaran untuk penguatan, model ini setidaknya untuk Kudus, lebih visibel untuk dilakukan karena sudah "diterapkan" oleh beberapa madrasah. Kekurananya hanya satu, selama ini antara madrasah dan pesantren tidak ada kerjasama atau koordinasi, sehingga terkesan siswa yang nyanteri di pesantren lebih mirip mencari pemondokan untuk tempat tinggal. Kerjasama dalam konteks ini ditujukan untuk kepentingan koordinasi dan sinergi kegiatan. Langkah ini sangat dimungkan dan mudah untuk dilaksanakan karena apapun bentuknya antara madrasah dan pesantren secara historis memiliki ikatan dan sejarah panjang, terutama dalam konteks da'wah Islamiyah.

Ketiga,Madrasah Sistem Nilai Pesantren (MSNP), konsep model ketiga ini didasarkan atas asumsi bahwa sistem pendidikan pesantren dengan meteri dan kulturnya dipandang cocok atau sesuai dengan karakter MA, terutama dalam mewujudkan ciri khas Islam. Sebagaimana diketahui, pada pesantren ada unsurunsur yang secara kultural sejalan dan mendukung tercapainya tujuan pendidikan dengan ciri khas Islam. Seperti keberadaan kiai sebagai figur panutan, masjid sebagai pusat kegiatan pendidikan dan ibadah, pengajaran kitab kuning sebagai sumber pengetahuan agama Islam, dan asrama sebagai media penciptaan suasana sosial keberagamaan, lengkap dengan kondisi lingkungan pesantren sebagai sub 
kultur masyarakat sekitar. Untuk mempermudah dan memperjelas anatomis unsurunsur lingkungan madrasah dan pesantren serta adobsi sistemik dari sistem nilai dan tradisi pesantren, maka berikut akan penulis gambarkan dalam bentuk skema. Sebagaimana dua model Penguatan Pendidikan Agama (PAI) Bebasis Pesantren sebelumnya, maka model ketiga ini juga memiliki tiga aspek pokok sebagai komponen yang akan menjadi jelas dalam model dimaksud, yaitu: aspek pengelolaan, aspek kurikulum dan aspek suasana keagamaan.

\section{Komparasi antar Model Kurikulum Berbasis Pesantren Sebagai Model Penguatan PAI}

Setelah melakukan elaborasi atas beberapa tawaran modelKurikulum berbasis pesantren sebagai model penguatan pendidikan agama Islam, maka penulis akan membuat komparasi antar-ketiganya. Tujuannya jelas, yakni mencari kelemahan dan kekuatan antar-model, serta mencari peluang bagi “irisan konseptual" antar-model tersebut guna lebih mendekatkan tulisan ini kepada citacita Kurikulum berbasis pesantren.

Seperti diketahui, analisis pokok penelitian ini ialah perlunya perumusanulang pendidikan MA berbasis pesantren. Dalam kaitan ini, basis tersebut mengacu pada empat hal; basis ontologis, basis epistemologis, basis pedagogis, dan basis kultural. Pertama, basis ontologis. Basis ini hendak memberikan dasar ontologis dari pendidikan Islam. Yakni suatu ontologi pendidikan yang menempatkan manusia dalam ruang ontologi keislaman. Dalam kaitan ini, pendidikan Islam terkait dengan status hakiki manusia sebagai hamba Allah swt yang butuh mendekatkan diri, agar mampu berperan sesuai dengan kehendak Allah swt. Jadi ontologi pendidikan Islam akhirnya merupakan proses pembelajaran agar manusia bisa lebih mengenali tujuan penciptaannya, serta mengetahui tugas hidupnya. Dari sini pendidikan Islam akhirnya memuara pada dua status manusia, yakni manusia sebagai “abdullah" dan manusia sebagai "khalifatullah". 
Dari uraian ini kita menjadi mafhum mengapa model Madrasah Lingkungan Pesantren (MLP) belum ideal. Karena, Kurikulum berbasis pesantren tidak hanya dipahami secara teritorial. Artinya, Kurikulum berbasis pesantren bukan hanya sekedar persoalan letak madrasah yang secara geografis berada di dalam lingkungan pesantren. Hal ini sudah banyak kita temukan pada lembaga pesantren yang mendirikan madrasah di dalamnya. Motivasi pendirian tersebut sangat beragam, mulai dari motivasi bahwa pesantren memiliki dan menyadari kelemahannya sebagai lembaga pendidikan tradisional, sehingga perlu mendirikan madrasah yang merupakan proto-type dari lembaga pendidikan modern. Oleh karena itu, madrasah sebagai lembaga pendidikan modern, ingin melakukan modernisasi pesantren malaui jalur pendirian lembaga madrasah.

Sementara itu, gagasan kurikulum berbasis pesantren justru sebaliknya. Ia merupakan arus balik tradisi, di mana pesantren hendak mengembalikan madrasah ke akar tradisi pendidikan Islam. Jadi ia pertama-tama merupakan kehendak normatif, baru setelah itu menjadi kehendak pedagogis. Artinya, gagasan ini bersifat normatif sebab ia lahir dari keprihatinan normatif akan tercerabutnya madrasah dari nilai kepesantrenan. Cara pikir tersebut, tentu saja telah melampaui kritik pendidikan dan kritik kebudayaan. Dalam kritik ini, tradisi mengarus-balik, mengritik modernitas, dan hendak mengembalikannya ke dasar tradisi tersebut. Ia menjadi kritik kebudayaan, karena telah melakukan kritik kemasyarakatan yang dibentuk oleh pola modernis dalam sistem pendidikan nasional. Tentu madrasah tidak bermasalah dalam dirinya sendiri. Madrasah memiliki kelemahan, karena madrasah bagian dari sistem pendidikan formal kita yang banyak memiliki kelemahan. Pada titik ini, MLP tidak memenuhi syarat normatif tersebut, karena ia tidak berangkat dari kritik kebudayaan: kritik tradisi atas modernitas. Oleh karenanya, di dalam MLP, terjadi pemilahan antara madrasah dan pesantren, sehingga keduanya terpisah, baik secara kelembagaan, maupun sistem pendidikan. Yang penulis maksud sebagai kelembagaan di sini berarti kelembagaan pendidikan, sebab bisa saja MLP berada dalam satu lembaga, yayasan misalnya, namun dalam pelembagaan pendidikan, mereka tidak sama, dan tidak menyatu. 
Model MLP memiliki nilai positif, dari segi geo-institusional. Artinya, karena secara geografis dan institusional telah menyatu antara madrasah dan pesantren, maka memiliki kelemahan juga kekuatan. Jika MLP kekuatannya terletak pada kesatuan fisik antara madrasah dan pesantren. Sementara dalam MSNP, kekuatannya terletak dalam terdapatnya sebagian sistem nilai pesantren di madrasah. Kelemahan yang terdapat di MSNP ialah belum bersatunya pesantren dan madrasah secara kelembagaan, dengan pesantren sebagai basis kulturalnya. Sebab secara manajerial pendidikan, MSNP sangat potensial bagi gagasan Kurikulum berbasis pesantren tersebut. Manajemen pendidikan MSNP telah mengacu pada kurikulum pendidikan pesantren. Hal ini cukup sebagai modal bagi gagasan Kurikulum berbasis pesantren. Maka untuk MSNP, langkah menuju Kurikulum berbasis pesantren tinggal setahap. Yakni penyatuan institusional antara madrasah dan pesantren. Tentu hal ini membutuhkan biaya besar, jika dibanding dengan MLP, sebab secara fisik, MSNP haruslah mendirikan pesantren di dalam lingkungan madrasah, sebagai basis kultural bagi pendidikan madrasah.

Dari model-model yang peneliti tawarkan, model Madrasah Pesantren (MP) merupakan paling ideal untuk sebuah proses pendidikan, tidak hanya untuk pendidikan Islam (madrasah) saja tetapi juga untuk semua lembaga pendidikan pada umumnya. Dengan sistem atau model ini akan tercipta proses pendidikan holistik yang akan melahirkan output dan outcome pendidikan berkualitas. Seperti telah diuraikan pada kerangka konsep di atas, pada MP ada tiga aspek penting yang memungkinkan berlangsungnya proses pendidikan di MA yang berorientasi pada kualitas, yaitu aspek pengelolaan, aspek kurikulum dan aspek suasana keagamaan.

\section{Kesimpulan}

Desain Pendidikan Agama Islam (PAI) pada Madrasah Aliyah di Kudus didasarkan kepada spirit dan nilai kepesantrenan sebagai bagian utama dari tradisi Islam dan sekaligus memenuhi kualifikasi standar nasional pendidikan. Madrasah saat ini, cenderung kehilangan jati diri kemadrasahan yang sesungguhnya menjadi pembeda dengan sekolah. Bukti tentang ini dapat dilihat struktur dan 
komposisi kurikulum yang minimalis untuk Pendidikan Agama Islam (PAI). Meskipun demikian, Madarasah Aliyah di Kabupaten Kudus dalam pelaksanaan pendidikan dan pembelajarannya menerapkan dan berpedoman pada kurikulum nasional Departemen Agama dan implementasinya memiliki karakteristik dan orientasi akademik yang berbeda antara satu madrasah dengan lainnya.

Kurikulum berbasis pesantren lahir dari krisis konseptual pendidikan Islam madrasah yang semakin jauh dari sistem nilai dan kultur pendidikan Islam salafi dan berikhtiar menawarkan solusi konseptual. Salah satu wujud dari sifat konseptual kurikulum berbasis pesantren adalah perumusan ulang kurikulum madrasah dengan menggunakan standar kurikulum pesantren. Sebagai konsep penguatan, kurikulum berbasis pesantren secara otomatis meniscayakan reformasi kelembagaan. Artinya, satu sisi Kurikulum berbasis pesantren menyatu dengan pesantren secara integral (MP), bersinergi dengan pesantren sekitar (MLP) maupun dengan mengadopsi sistem nilai dan kultur pesantren (MSNP).

Dengan demikian, maka pendidikan Islam di Indonesia tidak hanya disebut sebagai sistem sekolah berciri khas Islam. Akan tetapi madrasah berciri khas pesantren. Artinya, sistem pendidikan Islam memang bisa disamakan dengan sekolah, akan tetapi hanya pada level teknis manajerial. Secara substantif, ia berbeda dengan sekolah, sebab Islam sebagai sistem pendidikan memiliki konsepnya sendiri. Untuk itu, pendidikan Islam di Indonesia harus ditingkatkan dari sistem sekolah berciri Islam, menjadi sistem madrasah berciri pesantren. Dengan cara ini, maka pendidikan Islam bisa lebih memiliki kekhasan, yakni kepesantrenan. Kekhasan keislaman yang dirumuskan oleh Kemenag RI terbukti masih bersifat permukaan dan tidak menghunjam hingga ke dasar peradaban dan tradisi Islam. Dengan menjadikan pesantren sebagai basis pendidikan Islam, maka pendidikan Islam Indonesia bisa betul-betul mengakar pada tradisi keislamannya sendiri. 


\section{Daftar Pustaka}

Al-Attas, S. M. N. (1978). Islam and Secularism. (KualaLumpur: Muslim Youth Movement of Malaysia.

. (1980). The Concept of Education in Islam: A Framework for an Islamic Philosophy of Education. Kuala Lumpur: Muslim Youth Movement of Malaysia.

Azra, A. (2002). Paradigma Baru Pendidikan Nasional; Rekonstruksi danDemokratisasi. Jakarta: Penerbit Buku Kompas.

(2003). Pendidikan Islam Tradisional dalam Transisi dan Modernisasi. Jakarta: Logos.

Dhofier, Z. (1994). Tradisi Pesantren: Studi Tentang Pandangan Hidup Kyai. Jakarta: LP3ES.

Fealy, G. (ed), Ahmad Suaedy (terjemahan). (1997). Tradisionalisme Radikal: Persinggungan Nahdlatul Ulama-Negara. Yogyakarta: LKIS.

Guba, E. G. \& Lincoln, Y. S. (1995). Effective Evaluation H.A. MalikFadjar dalam Kontekstualisasi Ajaran Islam 70 Tahun Munawir Sjadzal. Jakarta: Kerja samaIPHI dan Paramadina.

Kutoyo, S. S.\& Slamet. (1986).Sejarah Pendidikan Daerah Jawa Timur. Surabaya: Proyek Inventarisasi dan Dokumentasi Kebudyaan Daerah.

Madjid, N. (1977). Bilik-BilikPesantrenSebuahPotretPerjalanan. Jakarta:Paramadina. . (1997). Bilik-Bilik Pesantren. Jakarta: Paramadina.

Mastuhu. (1994). Dinamika Sistem Pendidikan Pesantren, Suatu Kajian Tentang Unsur dan Nilai Sistem Pendidikan Pesantren. Jakarta: INIS.

Moestopo, M.H. (2001). Kebudayaan Islam di Jawa Timur: Kajian Beberapa Unsur Budaya Masa Peralihan. Yogyakarta: Jendela.

Muhadjir,N. (2002). Metodologi Penelitian Kualitatif. Yogyakarta: Rakesarasin. - Metodologi penelitian kebijakan dan evaluation research. Yogyakarta: Rake Sarasin. 
Ihsan

Muhaimin, et al.(2002).Paradigma Pendidikan Islam: Upaya Mengefektifkan Pendidikan Agama Islam di Sekolah. Bandung: PT Remaja Rosdakarya.

Mulkhan, M. (2002). Nalar Spiritual Pendidikan. Yogyakarta: Tiara Wacana.

Nasution. (1993).Pengembangan Kurikulum. Bandung: PT Citra Aditya Bakti.

Sirozi, M. (2005).Politik Pendidikan; Dinamika Hubungan antara Kepentingan Kekuasaan dan Praktik Penyelenggaraan Pendidikan. Jakarta: Raja Grafindo Persada.

Steenbrink, K. A. (1986).Pesantren Madrasah Sekolah: Pendidikan Islam dalam Kurun Modern. Jakarta:LP3ES.

Sugiyono. (2005).Memahami Penelitian Kualitatif. Bandung; Alfabeta.

Sumber data Kantor Kementerian Agama Kabupaten Kudus tahun 2010.

Supaat. (2009). Model Transformasi Madrasah sebagai Sekolah Umum Berciri Khas Islam. T.kt : t.p.

Wahid,

M. ( 1999 ). PesantrenMasaDepan; Wacana PemberdayaandanTransformasiPesantren. Bandung:PustakaHidayah.

Zuhairini, dkk. (1995).Filsafat Pendidikan Islam. Jakarta: Bumi Aksara.

Zuhri, S. (t.th). PendidikanPesantrendiPersimpanganJalan, dalam:MarzukiWahid (ed),PesantenMasa Depan". 